\title{
Comparative Study of Aqueous and Ethanolic Leaf Extracts Of Spondias Mombin on Neurobehaviour in Male Rats
}

\author{
O. R Asuquo ${ }^{1 *}$, C .E Fischer ${ }^{1}$, O. E. Mesembe ${ }^{1}$, A. O. Igiri ${ }^{1}$, J .I Ekom ${ }^{2}$ \\ ${ }^{I}$ Department of Human Anatomy, College of Medical Sciences, University of Calabar, Calabar. PMB 1115, \\ Nigeria. \\ ${ }^{2}$ Department of Physiology, College of Medical Sciences, University of Calabar, Calabar. PMB 1115, Nigeria.
}

\begin{abstract}
Remedies for anxiety and fear have been investigated through both orthodox and traditional medicine; this study compared the effects of chronic administration of graded doses of aqueous and ethanolic extracts of Spondias mombin on anxiety and fear in Albino Wistar rats. Fifty rats of Wistar strain (100-120g body weight) were divided into five major groups $A-E$ with each group made up of ten rats $(n=10)$. Spondias mombin $(250,400,500$ and $800 \mathrm{mg} / \mathrm{kg})$ were orally administered for 4 weeks before testing. The elevated plus maze was used to assess anxiety behaviour. Following administration of graded doses of aqueous and ethanolic extracts of Spondias mombin for a period of four weeks, decreased anxiety and fear in the albino rats was revealed $(p<0.05)$. The order of the anxiolytic property following these graded dose of administration was; duration and frequency in open arm of the $500 \mathrm{mg} / \mathrm{kg}$ group was significantly higher $(90.2 \pm 37.2 \mathrm{~s} \& 4.4 \pm$ 1.29/5min respectively) compared to control, and other treatment groups of Spondias mombin $(P<0.05)$. Duration in closed arm $(260.33 \pm 15.97 s)$ was significantly lower compared to control. Closed arms frequency with $250 \mathrm{mg} / \mathrm{kg}$ and $500 \mathrm{mg} / \mathrm{kg}$ ethanol extract were $3.83 \pm 1.74 / 5 \mathrm{~min}$ and $3.16 \pm 1.40 / 5 \mathrm{~min}$. The extracts were significantly $(P<0.05)$ lower compared with control $(8.67 \pm 1.05 / 5 \mathrm{~min})$. However, the $500 \mathrm{mg} / \mathrm{kg}$ ethanol extract showed a lower frequency. The duration of grooming following four weeks of treatment with $250 \mathrm{mg} / \mathrm{kg}$ and $500 \mathrm{mg} / \mathrm{kg}$ ethanol extract of Spondias mombin were $8.68 \pm 2.10 \mathrm{~s}$ and $12.1 \pm 0.001 \mathrm{~s}$ respectively and these were significantly lower compared to control. Spondias mombin dose-dependently decreased anxiety and fear with significant decrease observed in rats administered with ethanolic extracts of Spondias mombin. Anxiolytic effect is shown by decrease in the frequency of grooming and duration of grooming, decrease in frequency of head dipping and stretch attempt posture (SAP), and a lower frequency of close arm entry by the experimental groups. Ethanolic extract from Spondias mombin produced better behavioral effects with decreased anxiety and fear compared to the aqueous extract and so has a potential as an alternative anxiolytic and sedative agent compared to its aqueous extract.
\end{abstract}

Keywords: Spondias mombin, Fear, Anxiety, Frequency, Duration, Ethanol, Elevate plus maze.

\section{Introduction}

Neurobehavioral test is a non-invasive method employed to evaluate the performance of the central nervous system in an individual or group with similar exposures. Herbs are an integral part of the development of modern civilization, much of the medicinal use of plants seems to have been observed through observation of wild animals, and by trial and error (1). Medicinal plants are distributed worldwide, but they are most abundant in tropical countries (2). People from developing Countries especially Africans still resort to the use of herbs despite advances and availability of Orthodox medicine. Herbal medicines are used for the treatment of mental disorders in Nigeria due to its affordability and the belief that the main causes of mental disorders are supernatural $(3,4)$. Plants have been known for their medicinal properties in the central nervous system and used to influence brain function (5). Reports from other Continents have also shown the use of traditional medicine especially in China and the United States of America in the treatment of psychiatric disorders. $(6,7)$.

Spondias mombin $(S p)$ is one of the herbs used for the treatment of psychiatric disorders in Nigeria; it belongs to the family Anacardiaceae. Herbal preparations of Spondias mombin are used by traditional medicine practitioners in the treatment of mental disorder in Western Nigeria (8). $S p$ is relied on for various herbal remedies for numerous conditions and virtually every part of the tree is used; from its thick corky bark, to its leaves, fruits, roots to even its flowers. The leaves are considered to be antiviral, antibacterial, anticandidal, and antiseptic. It is also used in numerous microbial problems; colds and flu, cystitis, urethritis, sore throats, herpes, yeast infections, gonorrhea, eye and ear infections, and used externally for infected wounds, cuts, burns and rashes. Researches have been carried out on Spondias mombin, and it was found that most of the results correlated with its traditional uses. It has been reported to be non-toxic (9). Its pharmacological activities have been reported (10-23). Recently we reported its antigonadotrophic and antifertility effects (24-25) .

Therefore this research was aimed at comparing the effect of graded doses of ethanolic and aqueous extracts of Spondias mombin on behavioural parameters such as fear and anxiety in rats. 


\section{Materials and method}

Fifty male rats of Wistar strain (100-120g body weight) purchased from the Department of Zoology, University of Calabar, Nigeria, were housed in a standard facility of the Department of Human Anatomy, University of Calabar, Nigeria. The animals had access to rat chow from Agrofeed Nigeria Limited and water ad libitum. The rats were divided into five main groups A-E made up of control and four experimental groups. Each group was made up of ten rats.

\subsection{Preparation of ethanolic and aqueous leaf extracts of Spondias mombin}

The plant Spondias mombin was identified in the botanical garden of the University of Calabar, Nigeria and a sample deposited in the University herbarium with the voucher number MIA 313. The leaves of the plant were harvested, washed and sun-dried before blending to fine powder which was stored in a cool dry place, until required for use. $110 \mathrm{~g}$ of dried powdered leaves was separately extracted with water and ethanol. Aqueous infusion of Spondias mombin leaves was prepared by mixing $100 \mathrm{mls}$ of distilled water upon $20 \mathrm{~g}$ of powdered sample. The mixture was allowed to stand for 30 minutes before filtration. Ethanol extract was obtained with 1:1 ethanol/ water ratio by sohxlet apparatus. The mixture was then centrifuged at about $3000 \mathrm{xg}$ for $5 \mathrm{~min}$ and the supernatant collected. The supernatants collected were cleaned of particles by suction filtration using Whatmann no 1. Filter paper and cellulose filter paper. The extracts were subsequently concentrated to dryness in vacuo at $40^{\circ} \mathrm{C}$ using a rotary evaporator and stored in a dessicator. These extractions gave a percentage yield of $0.5 \%$ and $3 \%$ for aqueous and ethanol extracts respectively.

\subsection{Herb preparation and treatment}

The aqueous and ethanolic leaf extracts of Spondias mombin were reconstituted to a stock concentration of $1 \mathrm{mg} / \mathrm{ml}$. Graded doses according to body weights of rats were administered. Group A served as control ( $0.5 \%$ saline), while groups B and C animals received $400 \mathrm{mg} / \mathrm{kg}$ body weight and $800 \mathrm{mg} / \mathrm{kg}$ body weight of the aqueous extract of Spondias mombin. Groups D and E received $250 \mathrm{mg} / \mathrm{kg}$ body weight and $500 \mathrm{mg} / \mathrm{kg}$ body weight of ethanolic extract of Spondias mombin. The extracts were administered orally with the aid of an orogastric tube and lasted for 28 days. The last treatment was 24 hours before behavioural testing for Spondias mombin.

\subsection{Behavioural assay}

The elevated plus maze (EPM) test, which provides test of anxiety and exploration was used for this study. The elevated plus maze apparatus consists of two (2) open arms and two (2) closed arms in the sign of a plus the open arms are aversive to animals since they are open (26), the closed arms provide a sense of safety due to the enclosure. The arms measure (30x $5 \times 15 \mathrm{~cm}$ ). The floor of the maze was constructed from a $5 \mathrm{~cm}$ plank. The same plank was also attached to the floor of the open arms to prevent the rodent from falling off (27). Behaviour scored includes frequency of open arms entry, open arm duration, closed arm entries, close arm duration, grooming, and head dipping, frequency of stretch attend postures and rearing (28).

\subsection{Statistical analysis}

Data among the groups with different doses of extracts Spondias mombin was analysed by one- way analysis of variance (ANOVA) followed by post hoc Student's t-test. Data were presented as means \pm SEM, pvalue less than 0.05 was considered statistically significant.

\section{Results \\ 3.1 Comparison of duration and frequency of open arms entry in the elevated plus maze in rats} following 4 weeks treatment with aqueous and ethanolic extracts of Spondias mombin.

The duration in open arms following four weeks treatment with $400 \mathrm{mg} / \mathrm{kg}$ and $800 \mathrm{mg} / \mathrm{kg}$ aqueous extract of Spondias mombin were $15.25 \pm 10.40$ s and $26.2 \pm 5.29$ s respectively. These did not differ significantly when compared with control $(11.5 \pm 3.50 \mathrm{~s})$. The duration in the open arms following four weeks of treatment with $250 \mathrm{mg} / \mathrm{kg}$ ethanol extract of Spondias mombin was $15.8 \pm 9.01 \mathrm{~s}$ and this was also not significantly different from control. However, following treatment with $500 \mathrm{mg} / \mathrm{kg}$ ethanol extract of Spondias mombin, the duration in open arm $(90.2 \pm 37.2 \mathrm{~s})$ was significantly higher compared to control, $400 \mathrm{mg} / \mathrm{kg}$, $800 \mathrm{mg} / \mathrm{kg}$ aqueous extract and $250 \mathrm{mg} / \mathrm{kg}$ ethanol extract of Spondias mombin $(\mathrm{p}<0.05)$.

The frequency of open arms entry with $400 \mathrm{mg} / \mathrm{kg}$ and $800 \mathrm{mg} / \mathrm{kg}$ aqueous extract of Spondias mombin were $1.75 \pm 0.48 / 5 \mathrm{~min}$ and $2.8 \pm 0.58 / 5 \mathrm{~min}$ respectively and did not differ significantly from the control which was $1.0 \pm 0.001 / 5 \mathrm{~min}$. The frequency of open arms entry following four weeks of treatment with $250 \mathrm{mg} / \mathrm{kg}$ ethanol extract of Spondias mombin was $2.2 \pm 0.58 / 5 \mathrm{~min}$ and this was also not significantly different from control. Following treatment with $500 \mathrm{mg} / \mathrm{kg}$ ethanol extract of Spondias mombin however, the frequency of 
open arms entry $(4.4 \pm 1.29 / 5 \mathrm{~min})$ was significantly higher compared to control and $400 \mathrm{mg} / \mathrm{kg}$ aqueous extract ( $\mathrm{p}<0.05)$. This is shown in figs $1 \& 2$.

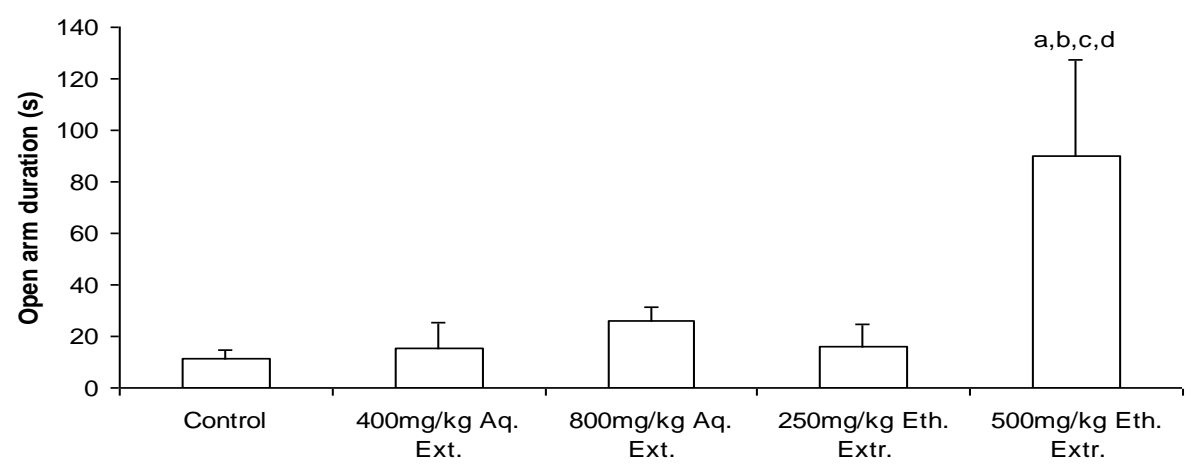

$\mathrm{a}=\mathrm{p}<0.05$ compared to control; $\mathrm{b}=\mathrm{p}<0.05$ compared to $400 \mathrm{mg} / \mathrm{kg}$ Aqueous extract; $\mathrm{c}=\mathrm{p}<0.05$ compared to $800 \mathrm{mg} / \mathrm{kg}$ Aqueous extract; $\mathrm{d}=\mathrm{p}<0.05$ compared to $250 \mathrm{mg} / \mathrm{kg}$ Ethanol extract.

Fig. 1: Comparison of duration in open arms of the elevated plus maze in rats following 4 weeks treatment with aqueous and ethanol extracts of Spondias mombin

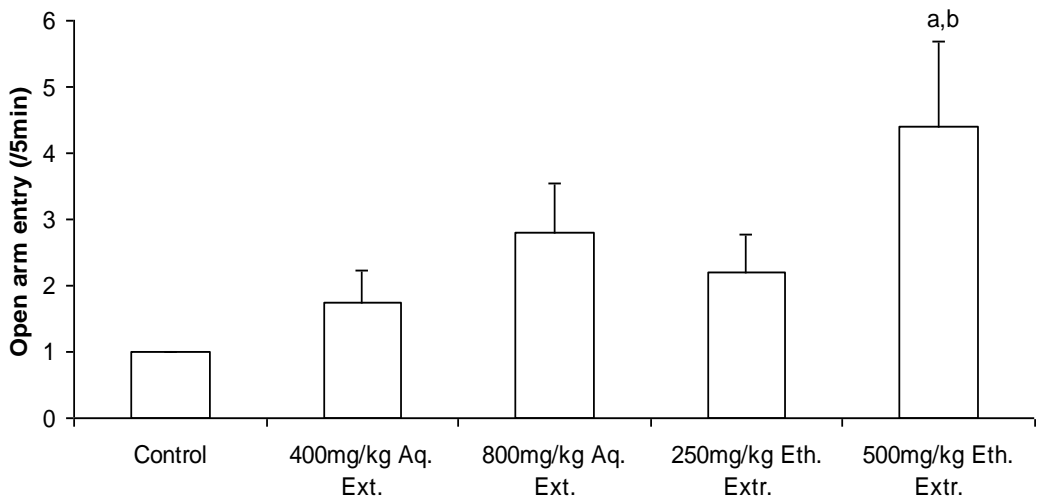

$\mathrm{a}=\mathrm{p}<0.05$ compared to control; $\mathrm{b}=\mathrm{p}<0.05$ compared to $400 \mathrm{mg} / \mathrm{kg}$ Aqueous extract

Fig. 2: Comparison of frequency of open arms entry in the elevated plus maze in rats following 4 weeks treatment with aqueous and ethanol extracts of Spondias mombin.

3.2 Comparison of duration and frequency in closed arms of elevated plus maze in rats following 4 weeks treatment with aqueous and ethanol extracts of Spondias mombin.

The duration in closed arms following four weeks treatment with $400 \mathrm{mg} / \mathrm{kg}$ and $800 \mathrm{mg} / \mathrm{kg}$ aqueous extract of Spondias mombin were $284.75 \pm 10.40$ s and278.17 $\pm 6.14 \mathrm{~s}$ respectively and did not differ significantly when compared with control $(296.17 \pm 2.58 \mathrm{~s})$. The duration in the closed arms following four weeks of treatment with $250 \mathrm{mg} / \mathrm{kg}$ ethanol extract of Spondias mombin was $286.83 \pm 7.81 \mathrm{~s}$ and this was also not significantly different from control. However, following treatment with $500 \mathrm{mg} / \mathrm{kg}$ ethanol extract of Spondias mombin, the duration in closed arm $(260.33 \pm 15.97 \mathrm{~s})$ was significantly lower compared to control, and $250 \mathrm{mg} / \mathrm{kg}$ ethanol extract of Spondias mombin ( $\mathrm{p}<0.05$ ). See fig 3

The frequency of closed arms entry with $400 \mathrm{mg} / \mathrm{kg}$ and $800 \mathrm{mg} / \mathrm{kg}$ aqueous extract of Spondias mombin were $3.83 \pm 2.06 / 5 \mathrm{~min}$ and $3.83 \pm 1.50 / 5 \mathrm{~min}$ respectively. Closed arms frequency with $250 \mathrm{mg} / \mathrm{kg}$ and $500 \mathrm{mg} / \mathrm{kg}$ ethanol extract were $3.83 \pm 1.74 / 5 \mathrm{~min}$ and $3.16 \pm 1.40 / 5 \mathrm{~min}$. The extracts were significantly $(\mathrm{p}<0.05)$ lower compared with control $(8.67 \pm 1.05 / 5 \mathrm{~min})$. However, the $500 \mathrm{mg} / \mathrm{kg}$ ethanol extract showed a lower frequency. Fig 4. 


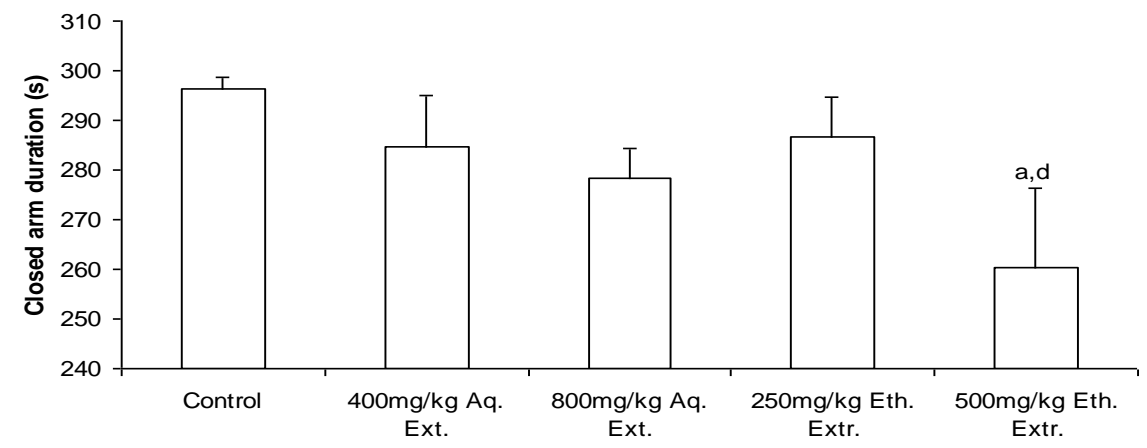

$\mathrm{a}=\mathrm{p}<0.05$ compared to control; $\mathrm{d}=\mathrm{p}<0.05$ compared to $250 \mathrm{mg} / \mathrm{kg}$ Ethanol extract

Fig. 3: Comparison of duration in closed arms of the elevated plus maze in rats following 4 weeks treatment with aqueous and ethanol extracts of Spondias mombin.

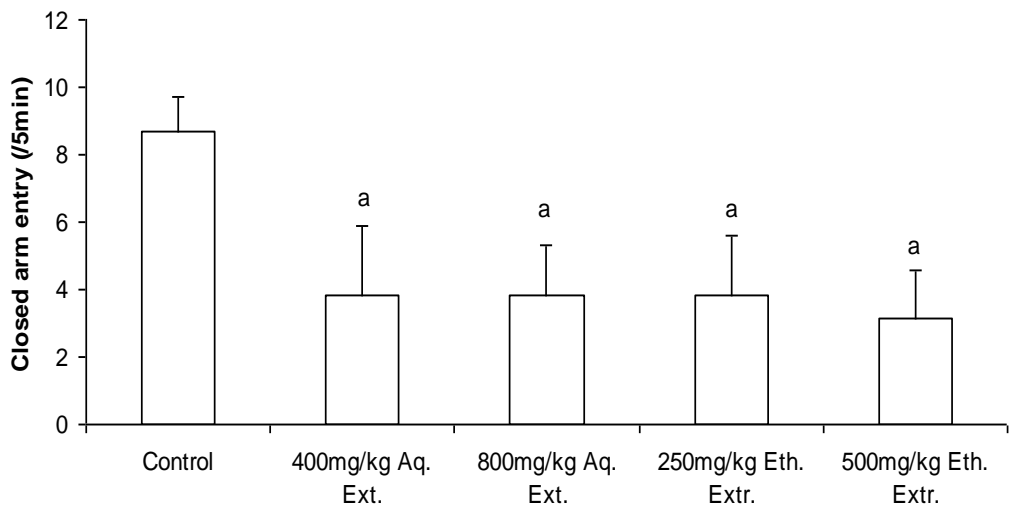

$$
\mathrm{a}=\mathrm{p}<0.05 \text { compared to control }
$$

Fig. 4: Comparison of frequency of closed arms entry in the elevated plus maze in rats following 4 weeks treatment with aqueous and ethanol extracts of Spondias mombin.

3.3 Comparison of duration and frequency of grooming in the elevated plus maze in rats following 4 weeks treatment with aqueous and ethanol extracts of Spondias mombin.

The duration of grooming following four weeks treatment with $400 \mathrm{mg} / \mathrm{kg}$ and $800 \mathrm{mg} / \mathrm{kg}$ aqueous extract of Spondias mombin $(15.57 \pm 7.97 \mathrm{~s}$ and $11.73 \pm 5.07 \mathrm{~s}$ respectively) were not significantly different compared to control $(22.2 \pm 5.26 \mathrm{~s})$. The duration of grooming following four weeks of treatment with $250 \mathrm{mg} / \mathrm{kg}$ and $500 \mathrm{mg} / \mathrm{kg}$ ethanol extract of Spondias mombin were $8.68 \pm 2.10 \mathrm{~s}$ and $12.1 \pm 0.001 \mathrm{~s}$ respectively and these were significantly lower compared to control. See fig 5 .

The frequency of grooming for the groups of rats treated with $400 \mathrm{mg} / \mathrm{kg}$ and $800 \mathrm{mg} / \mathrm{kg}$ aqueous extract of Spondias mombin were $4.41 \pm 1.28 / 5 \mathrm{~min}$ and $3.33 \pm 0.71 / 5 \mathrm{~min}$ respectively. These values were both significantly lower when compared to control $(7.83 \pm 1.01 / 5 \mathrm{~min} ; \mathrm{p}<0.05)$. the frequency of grooming for the groups treated with $250 \mathrm{mg} / \mathrm{kg}$ and $500 \mathrm{mg} / \mathrm{kg}$ ethanol extract of Spondias mombin were $2.0 \pm 0.63 / 5 \mathrm{~min}$ and $1.75 \pm 0.48 / 5 \mathrm{~min}$ respectively and these were also significantly lower than control $(\mathrm{p}<0.05)$. The frequency of grooming following treatment with $500 \mathrm{mg} / \mathrm{kg}$ ethanol extract was also lower than the $400 \mathrm{mg} / \mathrm{kg}$ aqueous extract $(\mathrm{p}<0.05)$. This decrease seemed dose dependent even though it did not significantly decrease at all doses of treatment. Fig 6 


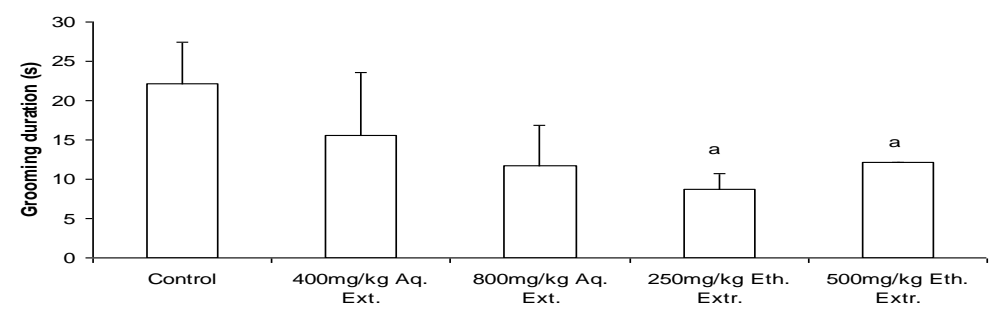

$\mathrm{a}=\mathrm{p}<0.05$ compared to control

Fig. 5: Comparison of duration of grooming in the elevated plus maze in rats following 4 weeks treatment with aqueous and ethanol extracts of Spondias mombin.

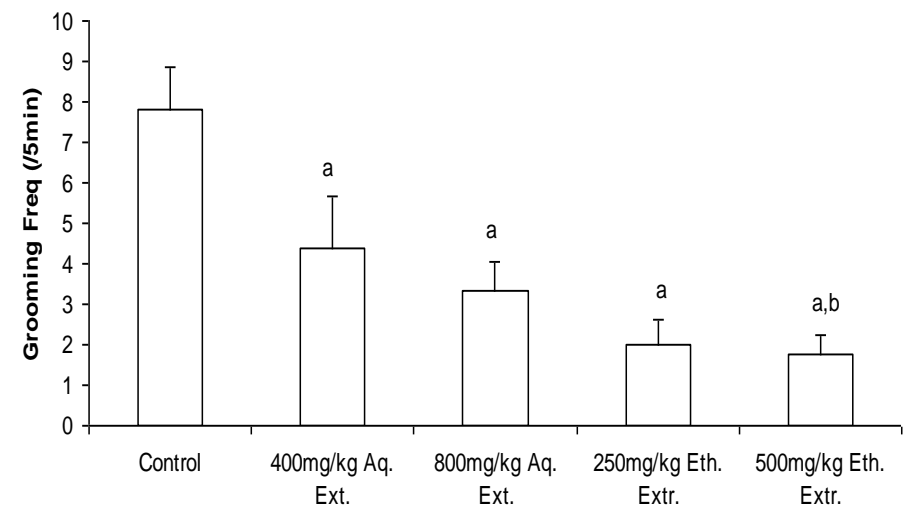

$\mathrm{a}=\mathrm{p}<0.05$ compared to control; $\mathrm{b}=\mathrm{p}<0.05$ compared to $400 \mathrm{mg} / \mathrm{kg}$ Aqueous extract

Fig. 6: Comparison of frequency of grooming in the elevated plus maze in rats following 4 weeks treatment with aqueous and ethanol extracts of Spondias mombin.

\subsection{Comparison of frequency of rearing in the elevated plus maze in rats following 4 weeks treatment} with aqueous and ethanol extracts of Spondias mombin.

Figure 7 shows that the frequency of rearing following treatment with both aqueous and ethanol extracts of Spondias mombin were significantly lower when compared to control $(16.33 \pm 1.75 / 5 \mathrm{~min} ; \mathrm{p}<0.05)$. The frequency of rearing for the $400 \mathrm{mg} / \mathrm{kg}$ and $800 \mathrm{mg} / \mathrm{kg}$ aqueous extract of Spondias mombin were $10.33 \pm 1.12$ and $9.17 \pm 1.83 / 5 \mathrm{~min}$ respectively while that for the $250 \mathrm{mg} / \mathrm{kg}$ and $500 \mathrm{mg} / \mathrm{kg}$ ethanol extract treated groups were $9.2 \pm 3.09$ and $6.0 \pm 1.15 / 5 \mathrm{~min}$ respectively. that for control wass $4.5 \pm 1.11 / 5 \mathrm{~min}$.

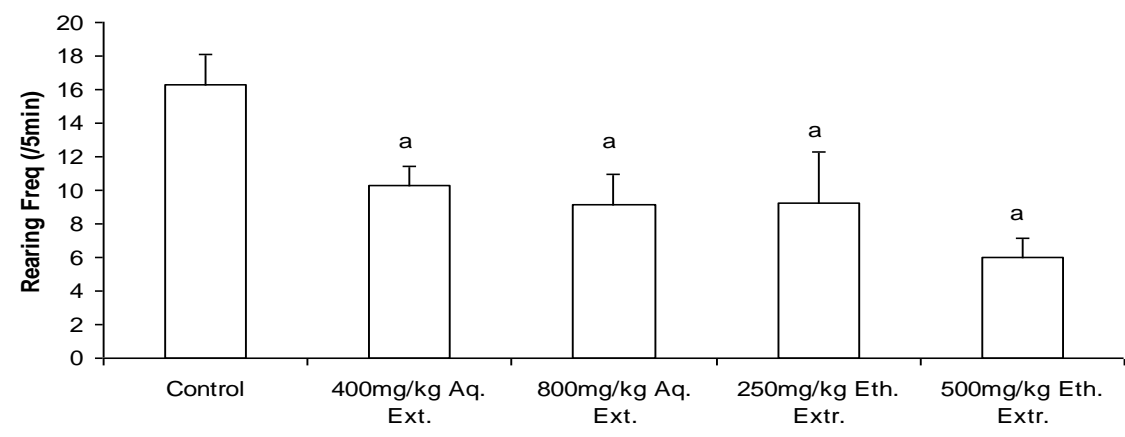

$\mathrm{a}=\mathrm{p}<0.05$ compared to control

Fig. 7: Comparison of frequency of rearing in the elevated plus maze in rats following 4 weeks treatment with aqueous and ethanol extracts of Spondias mombin. 
3.5 Comparison of frequency of head dips and stretch attend postures in the elevated plus maze in rats following 4 weeks treatment with aqueous and ethanol extracts of Spondias mombin

The frequency of head dips for all the treated groups did not differ from control. However, this was lower in the ethanol extract treated groups when compared to the $400 \mathrm{mg} / \mathrm{kg}$ aqueous extract group. Fig 8 . Figure 9 shows that the frequency of stretch attends postures were significantly lower in all the treated groups of animals when compared to control.

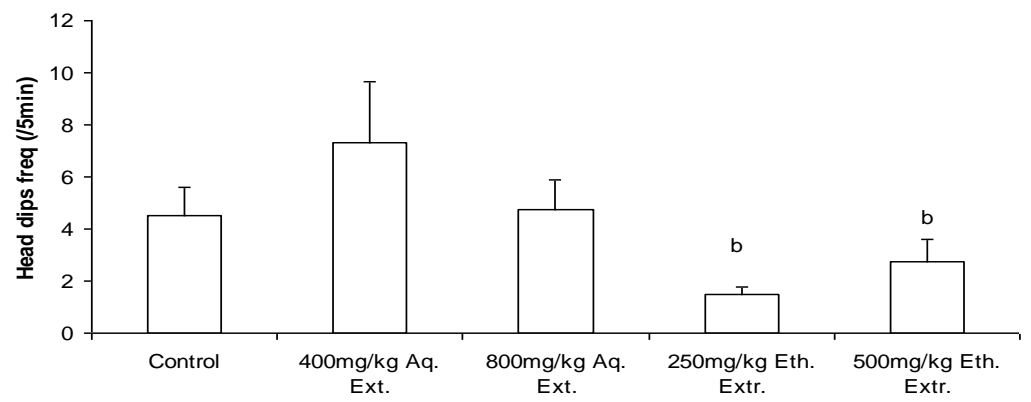

$\mathrm{b}=\mathrm{p}<0.05$ compared to $400 \mathrm{mg} / \mathrm{kg}$ Aqueous extract

Fig. 8: Comparison of frequency of head dips in the elevated plus maze in rats following 4 weeks treatment with aqueous and ethanol extracts of Spondias mombin.

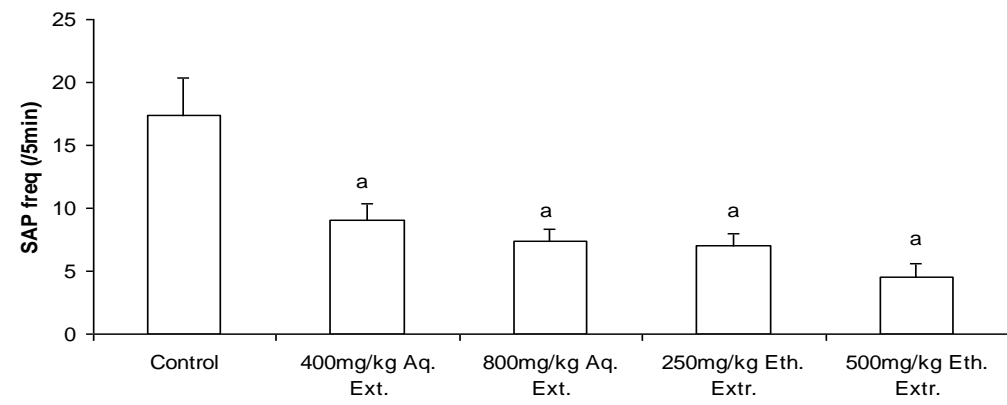

$\mathrm{a}=\mathrm{p}<0.05$ compared to control

Fig. 9: Comparison of frequency of stretch attend postures (SAP) in the elevated plus maze in rats following 4 weeks treatment with aqueous and ethanol extracts of Spondias mombin

\section{Discussion}

The elevated plus maze (EPM) is a typical test for anxiety / fear. At 4 weeks of treatment, the frequency of open arms entry and duration in open arms of the EPM were significantly higher for the $500 \mathrm{mg} / \mathrm{kg}$ ethanol extract. The motivation for the EPM is the open space and height. Rodents have a natural aversion for open space and height (26). Thus, fearful/anxious rats would spend less time in the open. The group of rats treated with $500 \mathrm{mg} / \mathrm{kg}$ ethanol extract was therefore less anxious compared to their control and lower doses of the extract. The closed arm entry and duration indicates the opposite effect. The closed arm duration is consistent with earlier results for the $500 \mathrm{mg} / \mathrm{kg}$ extract. Anxious rats will spend more time in the closed arms which feel safer. Since the group of rats treated with $500 \mathrm{mg} / \mathrm{kg}$ spent less time in the closed arm, they explored the open arms more.

Grooming is a displacement reaction (29). Rodents introduced into a novel environment would groom more as a sign of anxiety and apprehension. The frequency and duration of grooming was significantly lower for the groups of rats treated with $250 \mathrm{mg} / \mathrm{kg}$ and $500 \mathrm{mg} / \mathrm{kg}$ ethanol extract. The frequency of grooming in addition, showed a dose dependent decrease in the frequency of grooming. This decrease in frequency and duration of grooming for these doses indicate a decrease in anxiety.

The frequency of stretch attend postures is a risk assessment behaviour. An increase in this behaviour indicates increase hesitation to explore and therefore increased anxiety and vice versa. At all doses of treatment, the frequency of SAP was significantly lower than control. There was however no significant dose related effect even though it appeared dose related. 


\section{Conclusion}

The decreased anxiolytic effect of the leaf extracts of Spondias mombin may be due to its sedative and antipsychotic effect reported by Ayoka et al,(8) and Ayoka et al, (20). The anxiolytic activities observed with Spondias mombin leaf extracts may possibly be due to the presence of flavonoids, alkaloids and cardiac glycosides found in the plant extracts. These chemical constituents have been reported to be responsible for anxiolytic and sedative effects observed in different plant extracts (30-32).

\section{References}

[1] Huffman M.A. Animal self-medication and ethno-medicine: exploration and exploitation of the medicinal properties of plants. Pro Natural Society, 2003; 62 (2): 371-81.

[2] Farnsworth, N.R \& Morris, R.W. Higher plants- the sleeping giant of drug development. American J Pharmaceut Edu, 1976; 148: 522-546.

[3] Makanjuola, R. O. A. Yoruba traditional healer in psychiatry. Healers' concept of the nature and aetiology of mental disorders. African J Med \& Med Sci, 1987; 16: 53-59.

[4] Gureje, O., Acha, R. A. \& Odejide, O. A. Pathways to psychiatric care in Ibadan, Nigeria. Tropical Med and Int Health, 1995; 47: 125-129.

[5] Taesotikul, T, Panthong, A, Kanjanapothi, D, Verpoorte, R \& Schoffer, J. J. Neuropharmacological activities of the crude alkaloidal fraction from stem of Tabernaemontana Pandacaqui Poir. J. Ethnopharmacol, 1998; 62: 229-234.

[6] Kanba, S., Yamada, K., Mizushima, H and Asai, M. Use of herbal medicine for treating psychiatric disorders in Japan. $J$ Neuropsych and Clin Neurosci, 1998; 52: 331-333.

[7] Unützer, J., Klap, R, Sturm, R., Young, A. S., Marmon, T., Shatkin, J., \& Wells, K. B. Mental disorders and the use of alternative medicine: results from a national survey. American J Psych, 2000; 157: 1851-1857.

[8] Ayoka, A. O, Akomolafe, R. O, Iwalewa, E. O \& Ukponmwan, O. E. Studies on the anxiolytic effect of Spondias mombin L (Anacardiaceae) extracts. Afri J Trad, Compl Alter Med,2005; 2(2): 153-165.

[9] Asuquo, O.R, Ekanem, T.B, Eluwa, M.A, Oko, O.O \& Ikpi, D.E. Evaluation of toxicological effects of Spondias mombin in adult male rats. J Nat Sci Res, 2012a; 2(2): 144-151.

[10] Ajao, A. O. \& Shonukan, O. Antibacterial effect of aqueous and alcohol extracts of Spondias mombin and Alchomea cardifolia: two local antimicrobial remedies. Int J Crude Drug Res,1985; 23: 67 - 72.

[11] Corthout, J, Pieters, L. A, Claeys, M, Vanden-Berghe, D. A \& Viletinck, A. J. Antibacterial and molluscicidal phenolic acid from Spondias mombin. Planta Medica, 1994; 60: 460-463.

[12] Kramer, A, Mosquera, E, Ruiz, J \& Rodroguez, E. Ethnobotany and biological activity of plants utilized during pregnancy and childbirth in the Peruvian amazon. Emenations from the rainforest and the Carribean, 2002; Vol 4. Cornell University.

[13] Akubue, P,I., Mittal, G. C. \& Aguwa, C. N. Preliminary pharmacological study of some Nigerian medicinal plants. J Ethnopharmacol, 1983; 8: $53-63$.

[14] Uchendu, C. \& Nwankwo, I. O. Spasmogenic activity of butanolic leaf extract of Spondias mombin in isolated uterine muscle of the rat: role of calcium. $J$ Nat Rem, 2005; 5(1): 7-14.

[15] Caraballo,A, Caraballo, B \& Rodriquez-Acosta, A. Preliminary assessment of medicinal plants used as antimalarials in the southeastern Venezuelan Amazon. Revista-da-Scciedade-Brasileira-de-Medicna- Tropical 2004; 37(2): 186-188.

[16] Corthout, J, Pieters, L. A, Claeys, M, Vanden-Berghe, D. A \& Viletinck, A. J. Antiviral caffeoyl: esters from Spondias mombin. Phytochem, 1992; 31: 79-81.

[17] Abad, M. J, Bermejo, P, Carretero, E \& Martinez-Acitores, C (1996). Anti-inflammatory activity of some medicinal plant extracts fron Venezuela. J Ethnopharmacol, 1996; 55(1): 63-68.

[18] Kone-Bamba, D. Y, Pelissier, Y, Ozoukou, Z. F \& Kouao, D. A study of the haemostatic activity of fifteen medicinal plants of the traditional pharmacopoeia of Ivory Coast. Plantes-Medicinale-et-phytotherapie, 1987; 21(2): 122-130.

[19] Offiah, V. N \& Anyanwu, I. I. Abortifacient activity of an aqueous extract of Spondias mombin leaves. J Ethnopharmacol, 1989; 26: $317-320$

[20] Ayoka, A. O, Akomolafe, R. O, Iwalewa, E. O, Akanma, M. A \& Ukponmwan, O. E. Sedative, epileptic and antipsychotic effects of Spondias mombin L (Anacardiaceae) in mice and rats. J Ethnopharmacol, 2006; 103(2): 166-175.

[21] Coates, N. J, Gilpin, M. L, Gwynn, M. N, Lewis, D.E, Milner, P. H, Spear, S. R \& Tyler, J. W. SB-202742, a novel beta-lactamase inhibitor isolated from Spondias mombin. J Nat Prod, 1994; 57: 654-657.

[22] Pauly, G \& Fleury, M. Cosmetic containing plant extracts. Official Gazette of U. S patents and Trademark office. Patents, 2002; 1259(3): 34-57.

[23] Igwe, C. U, Ojiako, A. O, Nwaogu, L. A \& Onyeze, G. O. C. Lipid lowering effect of aqueous leaf extract of Spondias mombin Linn. Internet J Pharmacol, 2008; 6(1): 1-9.

[24] Asuquo, O.R, Ekanem, T.B, Udoh, P.B, Eluwa, M.A and Mesembe, O.E. Antigonadotrophic effect of Spondias mombin leaf extract in male Wistar rats. $J$ Biol, Agric Healthcare, 2013; 2(7):14-17.

[25] Asuquo, O.R, Ekanem, T. B, Udoh, P. B, \& Eluwa, M. A. Histomorphological study of the antifertility effect of Spondias mombin L. in adult male rats. IOSR J Pharm Biol Sci, 2012; 3(2): 29-34.

[26] Lister, R. G. Ethologically- based animal models of anxiety disorders. Pharmacol Theory, 1990; 46: 321-340.

[27] Trullas, R and Skolnick, P. Differences in fear motivated behaviours among inbred mouse strains. Psychopharmacol, 1993; 111: 323-331.

[28] Brown, R. E., Corey, S. C. \& Moore, A. K. Differences in measures of exploration and fear in MHC-congenic C57B1/6J and B6-H2k mice. Europ J Pharmacol, 1999; 463, 55-65.

[29] Espejo, E. F. Effects of weekly or daily exposure to the elevated plus maze in Male mice. Behavioural Brain Res, 1997; 87: 233238.

[30] Houghton, P. J. The scientific basis for the reputed activity of valerian. J Pharma Pharmacol, 1999; 51: 505-512.

[31] Dhawan, K. Kumar, S and Sharma, A. Antianxiety studies on extracts of Passiflora incamata Linneaus. J Ethnopharmacol, 2001; 78: $165-170$

[32] Carlini, E.A. Plants and the central nervous system. Pharmacol, Biochem Behav, 2003; 75, 501-512. 